\title{
Occupational stress of academic staff in South African higher education institutions
}

\author{
N. Barkhuizen \\ WorkWell: Research Unit for People, Policy and Performance, North-West University, \\ Potchefstroom Campus, South Africa
}

\author{
S. Rothmann \\ WorkWell: Research Unit for People, Policy and Performance, North-West University, \\ Potchefstroom Campus, 2520, South Africa \\ lan.Rothmann@nwu.ac.za
}

The objectives in this study were to identify the indicators of occupational stress for academic staff in South African higher education institutions, to analyse the differences between the occupational stress of different demographic groups, and to investigate whether occupational stressors predict ill health and a lack of organisational commitment of academics in higher education institutions. A cross-sectional survey design was used $(N=595)$. An Organisational Stress Screening Tool (ASSET) and a biographical questionnaire were administered. Compared to the normative data, academics reported higher levels of stress relating to pay and benefits, overload and work-life balance. Analysis of variance revealed differences between the levels of occupational stress and ill health of demographic groups. Two stressors, namely, overload and work-life balance contributed significantly to ill health of academics. Four occupational stressors, overload, job control, resources and communication, and job characteristics contributed significantly to the commitment of academics to their institutions.

Keywords: occupational stress; physical ill health; psychological ill health; organisational commitment; higher education institutions, South Africa

There is now overwhelming evidence attesting to what many academics have known for years: academia is a highly stressful occupation. In fact, academics throughout the world deal with a substantial amount of ongoing occupational stress (see Kinman, 2001, for a review). Ironically, university teaching has traditionally been conceived as a relatively stress-free occupation, or at least has been seen in this way by outsiders (Fisher, 1994). Although they are not highly paid in comparison to professionals in the commercial sector, academics have been envied for their tenure, light work loads, flexibility 'perks' such as overseas trips for study and/or conference purposes and the freedom to pursue their own research (Gillespie, Walsch, Winefield, Dua, \& Stough, 2001). However, with many of these attractions and advantages being eroded over the past two decades, it comes as no surprise that higher education institutions are now commonly labelled as 'stress factories'.

Concerns about academic stress have been articulated over the past three decades, dating back to the early 1970s. Despite this blossoming literature on work stress, the term stress is still enshrouded by a thick veil of confusion and divergence of opinion. As a result, stress has been variously defined as a response to challenging events (Selye, 1976), as an event that places demands on the individual (Kahn, Wolfe, Quinn, Snoek, \& Rosenthal, 1964), as an environmental characteristic which poses a threat to the individual (French, Kaplan, \& Harrison, 1982), and as a realisation by the individual that he/she is unable to deal adequately with the demands placed upon him/her (Lazarus, 1991). These various definitions can perhaps be summarised as follows: the nature and effects of stress might be best understood as arising from the interpretation by the individual (cognitive interpretation) of certain some environmental variables (stressors) as stress-inducing. 
Research conducted in the United Kingdom (UK), Unites States of America (USA), Australia and New Zealand has identified several key stressors commonly associated with stress among academic staff. These include work overload, time constraints, lack of promotion opportunities, inadequate recognition, inadequate salary, changing job role, inadequate management and/or participation in management, inadequate resources and funding and student interactions (Blix, Cruise, Mitchel, \& Blix, 1994; Boyd \& Wylie, 1994; Cross \& Carroll, 1990; Daniels \& Guppy, 1994; Doyle \& Hind, 1998; Kinman, 1998). Other sources of stress, such as high self-expectations (Hind \& Doyle, 1996), job insecurity (Tytherleigh, Webb, Cooper, \& Ricketts, 2005), lack of community and poor interactions with colleagues (Abouserie, 1996), inequality in the system (Gillespie et al., 2001), concerns over amalgamations (Sharpley, Reynolds, Acosta, \& Dua, 1996) and lack of regular performance feedback (Boyd \& Wiley, 1994) have been highlighted in a few studies.

Against a background of mounting research evidence, there can be little doubt that stress has a debilitating effect on both individual and organisational outcomes (Cooper \& Cartwright, 1994). In the academic context, occupational stress has specifically been associated with job dissatisfaction, increased smoking, alcohol and drug abuse, physical ill health (i.e. coronary heart disease) and poor psychological well-being (i.e. anxiety and depression) (Doyle \& Hind, 1998; Watts et al., 1991; Winefield, Gillespie, Stough, Dua, \& Hapuararchi, 2002). Furthermore, stress has been implicated as a causal factor of impaired work performance, decreases in faculty productivity, absenteeism, propensity to leave and higher staff turnover (Kinman, 2001; Taris, Schreurs, \& Van Iersel-Van Silfhout, 2001). Finally, occupational stress is also thought to have a spill over effect, whereby stress becomes a major determinant of the overall quality of life, including family life (Doyle \& Hind, 1998; Kinman \& Jones, 2003).

Clearly, higher education institutions have to manage and protect their staff from increasing levels of stress in order to preserve staff well-being, organisational performance and the intellectual health of a nation. However, to achieve this, a greater understanding of the effects of stress on staff within the higher educational sector is needed. The objectives of this study were therefore to identify the sources of occupational stress for academic staff in South African higher education institutions, to analyse differences between the occupational stress of different demographic groups, and to investigate whether organisational commitment moderates the effects of occupational stress on ill health.

\section{Occupational stressors, ill health and commitment}

Since the early work of Kahn et al. (1964), a great deal of attention has been devoted to understanding the stress-response in occupational settings. As a result, many different theories and models exist to explain the devastating effects of stress on the human being (see French et al., 1982; Karasek $\&$ Theorell, 1990). Based upon existing models of stress (i.e. Cooper and Marshall's (1976) Model of Stress at W ork), Cartwright and Cooper (2002) recently developed the ASSET (An Organisational Stress Screening Tool) model to measure an employee's potential exposure to stress and to recognise additional factors such as job satisfaction and organisational commitment, which serve to either exacerbate or moderate the stress levels experienced at work.

According to this model, the sources of stress commonly reported in literature can be classified in terms of eight different stressor categories. These include work relationships (i.e., poor or unsupportive relationships with colleagues and/or superiors, isolation and unfair treatment), work-life imbalance (i.e., when work interferes with the personal and home life of individuals), overload (i.e., unmanageable workloads and time pressures), job security (i.e., fear of job loss or obsolescence), control (i.e., lack of influence in the way work is organised and performed), resources and communication (i.e., having the appropriate training, equipment and resources), pay and benefits (i.e., the financial rewards that work brings) and aspects of the job itself (i.e., sources of stress related to the fundamental nature of the job itself). Commitment (including the individual's commitment to the 
organisation and the organisation's commitment to the individual) refers to an effect of stress. Poor health is an outcome of stress, and it can be used to ascertain if workplace pressures have positive and motivating or negative and damaging effects. However, poor health may not necessarily be indicative of workplace stress. Individuals may, for example, be unwell because they choose not to lead a healthy lifestyle or may be unaware of how to do so (Cartwright \& Cooper, 2002).

Although some studies found high levels of stress relating to work relationships, control, resources and communication and job insecurity (see Tytherleigh, 2003; Tytherleigh et al., 2005), excessive overload and work-life imbalance are among the most frequently reported stressors by academics (Association of University Teachers, 2003). In fact, 80 percent of the academics in Boyd and Wylie's (1994) study indicated that their workloads had expanded significantly in recent years. Also, with this escalation in the demands of the job, it is not surprising that academic staff report difficulty in maintaining firm boundaries between the workplace and the home as, for many, it appears that the home is the extension of the workplace (Kinman, 1998). The majority of academics (67\%) in Kinman and Jones's (2003) study agreed that work now encroached more on their home lives than in the recent past and 72 percent believed that their families suffered as a direct result of their jobs. More seriously, both work overload and work-life imbalance have been related to low psychological well-being among academics (Daniels \& Guppy, 1994; Kinman \& Jones, 2003; Winefield et al., 2002).

Generally speaking, psychological well-being amongst academics is relatively poor (see Kinman, 2001). Two-thirds of the respondents in Gillespie et al.'s (2001) study reported that stress impacted on them psychologically: they described experiencing feelings of anxiety, depression, burnout, anger, irritability and helplessness. Academic burnout in particular has been well documented (i.e. Blix et al., 1994; Doyle \& Hind, 1998). Moreover, depression has been associated with suicidal thoughts and tendencies (Watts et al., 1991). In fact, an epidemiological study of suicide conducted by Kelly, Charlton, and Jenkins (1995) suggest that university academic staff are at around 50 percent greater risk than the average worker. Psychological stress, in turn, can lead to severe physical consequences. In a study by Winefield et al. (2002), the majority of the respondents reported experiencing tiredness 'sometimes' to 'nearly all the time', back and neck pains, sleeping difficulties, headaches, muscle pain, colds and virus infections. Furthermore, in the South African context, Coetzee and Rothmann (2005) recently found high levels of psychological and physical ill health in a sample of 372 university staff members.

Results and conclusions regarding commitment among academics remain confusing and confounding. There is some evidence to suggest that, on average, academic staff appear to be committed to their organisations while experiencing stressors and strains (McInnis, 1999; Winefield et al., 2002). However, in the latter study, the strongest predictor of staff commitment to the university was trust in senior management. Similarly, Meyer and Allen (1997) also suggested that the organisation's support of academics explained their emotional commitment towards their universities. Interestingly, Coetzee and Rothmann (2005) found that while university staff members were committed to their institutions, they perceived a lack of commitment from their employer. In addition, Millward-Brown (1996) found that university and college lecturers reported lower levels of perceived commitment from their organisation when they were compared with 20 other occupational groups. Furthermore, Tytherleigh et al. (2005) found that all higher education staff reported significantly lower levels of commitment both from and to their organisation. However, despite the low commitment levels, staff members still experience low levels of stress relating to home-work balance, overload, the job overall and physical ill health.

Chui and Kosinski (1995) argued that organisational commitment, as an attitudinal variable, influences stress. Similarly, Sommer, Bae, and Luthans (1996) contended that organisational commitment is one of the important variables in the study of employee behaviour since it is inversely related 
to employee tardiness and absence. Chow (1990) furthermore found that highly committed employees are more productive and are willing to assume responsibility. Begley and Cazjka (1993) suggested that committed employees, because of their positive attitudes, are less distressed by occupational stressors and therefore they perceive less stress.

\section{Occupational stress and background variables}

Academics are not a homogeneous group of professionals. Therefore, it would be inappropriate to examine academic stress without taking all their professional and personal characteristics into account. With regard to gender, there are very few differences, if any, between male and female academics regarding the amount of occupational stress they experience and report. However, academics seem to differ significantly in terms of the work stressors they perceive. Research has shown that workload, inadequate salaries and a lack of public recognition were perceived as more significant sources of pressure by men than by women, whilst job insecurity, isolation from colleagues, a lack of institutional recognition of worth and work politics were more salient for women (Cross \& Carroll, 1990; Dua, 1994). Since academia is still largely a male dominated occupation, female academics might experience more stressors and strains than their male counterparts due to a lack of role models, less socialisation from women from their own rank, gender stereotypes and increased role conflict as they endeavour to balance roles at work and at home (Blix et al., 1994; Richard \& Krieshok, 1989). Both Kinman (1996) and Doyle and Hind (1998) found that, women academics in general experienced a higher degree of conflict between work and home. High workload, coupled with greater responsibilities for duties related to work and family, mean that women have to work long hours. Long working hours are now recognised as posing a serious threat to health and well-being (Cooper, 1999; Sparks \& Cooper, 1997).

Researchers have also noted the importance of age-based differences in faculty, and conventionally believe that stress universally declines with chronological age. Dua (1994) found that younger academic staff reported more stress as a result of work politics, working conditions and job significance than older staff. This is quite understandable since younger faculty are more often involved in undergraduate teaching as opposed to more rewarding tasks such as research (Gmelch, Wilke, \& Lovrich, 1986). The latter, however, is a prerequisite for advancement up the faculty career ladder. Coupled with an economy that reduces the chances for success to a greater extent than at any other time during the past decades, academics are thus under greater pressure to increase their research output, if they are to be retained, employed or promoted on this basis (Kinman \& Jones, 2003). Moreover, new academics also have to make sense of the organisational structures and values of their newly employing institution, learn the expectations for performance and advancement, and balance multiple and sometimes conflicting demands on their time (Sorcinelli, 1994). More seriously, Osipow, Doty, and Spokane (1985) found that younger academics are less likely to cope with occupational stressors, and therefore experience greater psychological and interpersonal strain than their older colleagues.

Older academics tend to have more responsibilities and often report increasing pressure and work overload (Dua, 1994; Winefield et al., 2002). In particular, Winter, Taylor, and Sarros (2000) found that both professors and associate professors reported significantly more role overload than lecturers did. Dua (1994) also reported that academics with postgraduate qualifications tend to have a heavier workload. Furthermore, Winefield et al. (2002) found that as occupational levels increased, so did working hours for associate professors and professors, who reported an average of 55-56 hours per week. However, Osipow et al. (1985) suggested that older academics use a variety of coping mechanisms and therefore report less perceived strain compared to younger academics.

The objectives in this study were to identify the indicators of occupational stress for academic staff in South African higher education institutions, to analyse the differences between the occupa- 
tional stress of different demographic groups, and to investigate whether organisational commitment moderates the effects of occupational stress on ill health.

\section{METHOD}

\section{Participants}

From the 2000 academics surveyed only 28.33 percent responded. Reasons for such a response rate may be that academics experience extreme work pressure and/or a lack of time and are therefore disinclined to fill out a questionnaire of this sort. The characteristics of the participants are given in Table 1.

Table 1. Characteristics of the participants

\begin{tabular}{|c|c|c|c|}
\hline Item & Category & Frequency & Percentage \\
\hline \multirow[t]{6}{*}{ University } & North-West University & 268 & 46.7 \\
\hline & University of Port Elizabeth & 77 & 12.9 \\
\hline & University of the Orange Free State & 86 & 14.5 \\
\hline & Rhodes University & 38 & 6.4 \\
\hline & University of the Witwatersrand & 45 & 7.6 \\
\hline & University of Cape Town & 71 & 11.9 \\
\hline \multirow[t]{5}{*}{ Job title } & Junior lecturer & 45 & 7.6 \\
\hline & Lecturer & 176 & 29.6 \\
\hline & Senior lecturer & 153 & 25.7 \\
\hline & Associate professor & 75 & 12.6 \\
\hline & Full professor & 117 & 19.7 \\
\hline \multirow[t]{6}{*}{ Qualification } & Grade $12+3$-year Degree & 17 & 2.9 \\
\hline & Grade $12+4$-year Degree or Honours & 67 & 11.3 \\
\hline & Grade $12+5$ - to 7-year Degree (e.g. Medicine) & 8 & 1.3 \\
\hline & Grade $12+$ Master's Degree & 200 & 33.6 \\
\hline & Grade $12+$ Doctoral Degree & 287 & 48.2 \\
\hline & Research & 47 & 8.1 \\
\hline \multirow[t]{3}{*}{ Focus } & Lecturing & 145 & 25.0 \\
\hline & Research and lecturing & 388 & 66.9 \\
\hline & Male & 297 & 49.9 \\
\hline \multirow[t]{2}{*}{ Gender } & Female & 298 & 50.1 \\
\hline & 20 to 29 years & 70 & 11.8 \\
\hline \multirow[t]{5}{*}{ Age category } & 30 to 39 years & 157 & 26.4 \\
\hline & 40 to 49 years & 182 & 30.6 \\
\hline & 50 to 59 years & 140 & 23.5 \\
\hline & 60 to 69 years & 42 & 7.1 \\
\hline & Afrikaans & 380 & 63.9 \\
\hline \multirow[t]{2}{*}{ Language } & English & 207 & 34.8 \\
\hline & Permanent & 513 & 86.2 \\
\hline \multirow[t]{2}{*}{ Tenure } & Temporary & 35 & 5.9 \\
\hline & Fixed-term & 44 & 7.4 \\
\hline
\end{tabular}

Most of the participants were from North-West University, with nearly a third of the sample lecturers $(29.6 \%)$. In total 48.2 percent of the participants were in possession of a doctoral degree. Female participants constituted 50.1 percent of the sample, were married $(49.9 \%)$ and between the ages of 40 and 49 years (30.6\%). Most academics held a permanent appointment $(86.2 \%)$, and worked between 41 and 50 hours $(43.7 \%)$ in a typical work week. 


\section{Measuring instrument}

An Organisational Stress Screening Tool (ASSET) was used in this study. The ASSET was developed by Cartwright and Cooper (2002) as an initial screening tool to help organisations assess the risk of occupational stress in their workforce. It measures potential exposure to stress in respect to a range of common workplace stressors. It also provides important information on current levels of physical health, psychological well-being and organisational commitment, and provides data to which the organisation can be compared. The ASSET comprises three main scales: Perceptions of your job: 37 items scored from 1 (strongly disagree about being troubled) to 6 (strongly agree about being troubled); Attitudes towards your organisation (indicating organisational commitment): nine items scored from 1 (strongly disagree) to 6 (agree); Your health: 19 items on two subscales — physical health and psychological well-being - items scored from 1 (never experienced the ill health symptom or change of behaviour over the last three months) to 4 (often experiences the ill health symptom or change of behaviour over the past three months).

The ASSET has an established set of norms from a database of responses from 20000 workers in public-and private-sector organisations in the United Kingdom. The ASSET presents scores in sten (standardised ten-point scale) format. A sten is a standardised score based on a scale of 1 to 10 , with a mean of 5.5 and a standard deviation of 2 . The sten system makes possible meaningful comparison to the norm group. Most people (68\%) score between sten 4 and sten 7 . Scores that fall further from the mean (either in the high or the low direction) are considered more extreme. About 16 percent of people score at the low end, and another 16 percent score at the high end.

Reliability is based on the Guttman split-half coefficient. All but two factors returned coefficients in excess of 0.70 ranging from 0.60 to 0.91 (Cartwright \& Cooper, 2002). Tytherleigh (2003) used the ASSET as an outcome measure of job satisfaction in a nationwide study of occupational stress levels in 14 English higher education institutions. The Cronbach's alphas for the ASSET subscales vary from 0.64 to 0.94 , which show acceptable internal consistency. Johnson and Cooper (2003) found that the Psychological Well-Being subscale has good convergent validity, with an existing measure of psychiatric disorders, the General Health Questionnaire (GHQ-12; Goldberg \& Williams, 1988).

A biographical questionnaire was developed to gather information about the demographic characteristics of the participants. Information that was gathered included the following: city and university, gender, marital status, satisfaction with current relationship/marriage/single status, language, age, educational qualifications, job category, job title, main educational focus, years in current institution, years in current job, chances of promotion, basis of employment, working hours, amount of time travelling to and from workplace and annual leave.

\section{Statistical analysis}

The statistical analysis was carried out with the aid of the SPSS program (SPSS, 2003) and SAS program (SAS Institute, 2000). The reliability of the ASSET was determined by means of Cronbach's alpha coefficients. Descriptive statistics (i.e. means, and standard deviations) were used to analyse the data. Multivariate analysis of variance (MANOVA) was used to determine the significance of differences between occupational stress (i.e. job demands; lack of resources), ill health (physical and psychological) and organisational commitment of the demographic groups. MANOVA tests whether mean differences among groups on a combination of dependent variables are likely to have occurred by chance (Tabachnick \& Fidell, 2001). In MANOVA a new dependent variable, which maximizes group differences, is created from the set of dependent variables. One-way analysis is then performed on the newly created dependent variable. Wilks' Lambda was used to test the significance of the effects. When an effect was significant in MANOVA, ANOVA was used to discover which dependent variables were affected. Because multiple ANOVAs were used, a Bonferroni type adjustment was 
made for inflated Type 1 error. Standard multiple regression analysis was used to test whether occupational stressors would predict ill health and organisational commitment (Tabachnick \& Fidell, 2001).

\section{RESULTS}

\section{Descriptive statistics}

The descriptive statistics and Cronbach's alphas of the ASSET dimensions and items are reported in Table 2 . The sten scores reflect the mean scores of the participants compared to international norms $(N=20000)$.

Table 2 shows that the 12 dimensions of the ASSET have Cronbach's alpha coefficients, varying from 0.60 to 0.92 , which compare reasonably well with the guideline of 0.70 (Nunnally \& Bernstein, 1994). The alpha coefficients of three scales, namely, Job Security $(\alpha=0.60)$, Resources and Communication $(\alpha=0.61)$, and Job Characteristics $(\alpha=0.65)$, were slightly below the guideline of 0.70 . The internal consistency of these scales may be questionable.

Pay and Benefits, Work-life Balance, Work Relationships and Overload proved to be major sources of stress as reflected by sten scores of 6 and higher for these dimensions. Items such as 'I work longer hours than I choose or want to' and 'I work unsocial hours, e.g. weekends' contributed to the above-average sten of Work-Life balance. Overload was mainly predicted by items such as 'I do not have enough time to do my job as well as I would like', 'I am set unrealistic deadlines' and 'I am given unmanageable workloads'. This indicates that job demands per se are experienced as major sources of stress for academics in higher education institutions. W ork Relationships (e.g. other people at work not pulling their weight, and others taking credit for the individual's achievements) were experienced as stressful by the participants.

The sten scores of lower than 5 for Job Security, Control, and Job Characteristics indicated that these dimensions were perceived as low sources of stress among academics. Also, despite an average sten of 5.4 for Physical Ill health, academics seem troubled by sleep loss and muscular tension/aches and pains. Psychological ill health (e.g. avoiding contact with other people, constant irritability, and feeling unable to cope) proved to be a major negative outcome of stress. The levels of commitment of employees to their organisations were average.

A risk factor analysis was conducted following the procedure as suggested by Clarke and Cooper (2000). Clarke and Cooper proposed that the level of risk (or risk factor) associated with the likely negative effects of a given stressor may be calculated by weighting the sample mean (perceived level of a stressor) by the sample correlation (between the stressor and a stress outcome): Risk factor $=$ Exposure $(E) \times$ Consequences $(C)$ Therefore, $E$ is the perceived level of the stressor (exposure) and $C$ is the correlation between the stressor and stress outcome (consequences). A stress audit instrument, which measures the level of perceived stress, can be used to obtain E for a particular sample. It is necessary that the standardised scale sores, rather than raw scores be used. Values of $C$ (consequences) are obtained by calculating the correlation between the stressors and stress outcomes, and converting $r$ into $r^{2}$. The Asset includes measures of outcome variables (physical and psychological ill health and organisational commitment), allowing the calculation of correlations between the stressor and some stress outcomes. The weighting of the stress level $(E)$ by its correlation with a stress outcome $(C)$ gives an estimate of the risk associated with exposure to that stressor. The results are reported in Table 3 .

Although the absolute values in Table 3 are not interpretable, lower scores indicate relatively lower risk factors while higher scores indicate higher risk factors (in terms of ill health and low organisational commitment). Table 3 shows that Overload and Work-life Balance were the most important stressors that put academics at risk for physical ill health. Overload represents the highest risk factor for Psychological Ill Health, but four other stressors, namely Work-life Balance, Resources 
Table 2. Descriptive statistics and alpha coefficients of the ASSET

\begin{tabular}{|c|c|c|c|c|c|c|c|c|c|c|c|c|c|c|c|c|}
\hline & & Sten UK & Mean & SD & $\alpha$ & 1 & 2 & 3 & 4 & 5 & 6 & 7 & 8 & 9 & 10 & 11 \\
\hline 1. & $\begin{array}{l}\text { Work } \\
\text { Relationships }\end{array}$ & 6.03 & 19.45 & 7.33 & 0.84 & - & - & - & - & - & - & - & - & - & - & - \\
\hline 2. & $\begin{array}{l}\text { Work-Life } \\
\text { Balance }\end{array}$ & 6.65 & 12.50 & 4.38 & 0.72 & $0.35^{*}$ & - & - & - & - & - & - & - & - & - & - \\
\hline 3. & Overload & 6.48 & 12.03 & 4.43 & 0.73 & $0.51^{*}$ & $0.58^{*}$ & - & - & - & - & - & - & - & - & - \\
\hline 4. & Job Security & 4.99 & 10.29 & 3.84 & 0.60 & $0.31 *$ & $0.11 *$ & $0.22 *$ & - & - & - & - & - & - & - & - \\
\hline 5. & Control & 5.47 & 11.30 & 4.45 & 0.81 & $0.72 *$ & $0.32 *$ & $0.54^{*}$ & $0.38^{*}$ & - & - & - & - & - & - & - \\
\hline 6. & $\begin{array}{l}\text { Resources and } \\
\text { Communication }\end{array}$ & 5.52 & 11.03 & 4.06 & 0.66 & $0.64 *$ & $0.28^{*}$ & $0.54 *$ & $0.27^{*}$ & $0.67^{*}$ & - & - & - & - & - & - \\
\hline 7. & $\begin{array}{l}\text { Job } \\
\text { Characteristics }\end{array}$ & 2.66 & 17.27 & 5.17 & 0.61 & $0.58^{*}$ & $0.31 *$ & $0.48^{*}$ & $0.34^{*}$ & $0.56^{*}$ & $0.53 *$ & - & - & - & - & - \\
\hline 8. & $\begin{array}{l}\text { Pay and } \\
\text { Benefits }\end{array}$ & 6.87 & 3.99 & 1.62 & 0.83 & $0.30^{*}$ & $0.21 *$ & $0.35^{*}$ & $0.27^{*}$ & $0.30^{*}$ & $0.35^{*}$ & $0.31 *$ & - & - & - & - \\
\hline 9. & $\begin{array}{l}\text { Physical Ill } \\
\text { Health }\end{array}$ & 5.41 & 13.51 & 4.30 & 0.79 & $0.24 *$ & $0.26^{*}$ & $0.31 *$ & $0.18^{*}$ & $0.25^{*}$ & $0.22 *$ & $0.25^{*}$ & $0.15^{*}$ & - & - & - \\
\hline 10. & $\begin{array}{l}\text { Psychological } \\
\text { Ill Health }\end{array}$ & 6.23 & 24.28 & 7.45 & 0.92 & $0.38^{*}$ & $0.37 *$ & $0.47^{*}$ & $0.22 *$ & $0.40^{*}$ & $0.38^{*}$ & $0.36^{*}$ & $0.19^{*}$ & $0.67^{*}$ & - & - \\
\hline 11. & $\begin{array}{l}\text { Commitment } \\
\text { from } \\
\text { Organisation }\end{array}$ & 5.49 & 18.05 & 3.93 & 0.80 & $0.45^{*}$ & $0.17 *$ & $0.25^{*}$ & $0.29 *$ & $0.48^{*}$ & $0.45^{*}$ & $0.46^{*}$ & $0.27^{*}$ & $0.22 *$ & $0.34^{*}$ & - \\
\hline 12. & $\begin{array}{l}\text { Commitment } \\
\text { from Individual }\end{array}$ & 5.39 & 20.99 & 5.17 & 0.83 & $0.30^{*}$ & -0.09 & $0.15^{*}$ & $0.16^{*}$ & $0.35^{*}$ & $0.35^{*}$ & $0.35^{*}$ & $0.20^{*}$ & $0.17^{*}$ & $0.25^{*}$ & $0.77^{*}$ \\
\hline
\end{tabular}
from Individual

* Correlation is significant at the 0.01 level (2-tailed).

Note: Low sten scores for dimensions 1 to 10 indicate low stress and/or ill health. Low sten scores for dimensions 11 and 12 indicate low commitment. 
Table 3. Risk factor analysis

\begin{tabular}{lcccc}
\hline Stressor & $\begin{array}{c}\text { Physical ill } \\
\text { health }\end{array}$ & $\begin{array}{c}\text { Psychological ill } \\
\text { health }\end{array}$ & $\begin{array}{c}\text { Commitment } \\
\text { (Individual - } \\
\text { Organisation) }\end{array}$ & $\begin{array}{c}\text { Commitment } \\
\text { (Organisation - } \\
\text { Individual) }\end{array}$ \\
\hline $\begin{array}{l}\text { Work-Life } \\
\text { Balance } \\
\begin{array}{l}\text { Resources and } \\
\text { Communication }\end{array}\end{array}$ & 46.16 & 88.99 & 21.76 & 5.18 \\
$\begin{array}{l}\text { Work } \\
\text { Relationships }\end{array}$ & 25.64 & 79.86 & 118.61 & 72.43 \\
$\begin{array}{l}\text { Overload } \\
\text { Job Insecurity }\end{array}$ & 34.80 & 87.25 & 116.62 & 64.62 \\
$\begin{array}{l}\text { Job } \\
\text { Characteristics }\end{array}$ & 16.46 & 144.39 & 43.97 & 12.99 \\
Job Control & 16.50 & 24.05 & 30.58 & 27.01 \\
Pay & 33.17 & 34.97 & 56.81 & 35.34 \\
\hline & 16.14 & 87.62 & 128.12 & 75.36 \\
\hline
\end{tabular}

and Communication, Work Relationships, and Job Control also represented moderate risk factors in terms of Psychological Ill Health. Three stressors, namely Resources and Communication, Work Relationships and Job Control represented high risks in terms of Individual Commitment to the Organisation, as well as the Organisation's Perceived Commitment to Individuals.

\section{Differences between demographic groups}

The MANOVAs of the relationship between occupational stressors and demographic groups, including qualifications and academic rank are presented in Table 4.

Table 4. MANOVAs of occupational stressors of demographic groups

\begin{tabular}{lccccc}
\hline Variable & Wilks' Lambda & $\boldsymbol{F}$ & df & $\boldsymbol{p}$ & Partial $\boldsymbol{\eta}^{\mathbf{2}}$ \\
\hline Qualifications & 0.98 & 2.75 & 4,1148 & 0.03 & 0.00 \\
Academic rank & 0.94 & 4.69 & 8,1120 & $0.00^{*}$ & 0.03 \\
Gender & 0.99 & 2.57 & 2,592 & 0.77 & 0.00 \\
Age & 0.97 & 2.35 & 8,1170 & 0.02 & 0.02 \\
\hline
\end{tabular}

* Statistically significant $(p<0.01)$

Table 4 shows that academic rank impacted significantly on the combined dependent variable Occupational stressors $\left(F_{(8,1120)}=4.69, p<0.01\right.$; Wilks' Lambda $=0.94$; partial $\left.\eta^{2}=0.03\right)$. However, this effect was small (3\% of the variance explained). Analysis of each dependent variable, using a Bonferroni adjusted alpha level of 0.025 , showed that academics differed in terms of the level of Job demands $\left(F_{(4,565)}=3.36, p<0.01\right.$, partial $\left.\eta^{2}=0.02\right)$. Associate professors experienced higher levels of job demands than junior lecturers and lecturers. Results furthermore showed no gender and age differences in terms of occupational stress. The differences between the ill health of various demographic variables are reported in Table 5. 
Table 5. MANOVAs of ill health of demographic groups

\begin{tabular}{lccccc}
\hline Variable & Wilks' Lambda & $\boldsymbol{F}$ & df & $\boldsymbol{p}$ & Partial $\boldsymbol{\eta}^{\mathbf{2}}$ \\
\hline Gender & 0.96 & 12.82 & 2,592 & $0.00^{*}$ & 0.04 \\
Age & 0.96 & 3.39 & 8,1170 & $0.00^{*}$ & 0.02 \\
Academic rank & 0.97 & 1.96 & 8,1120 & 0.05 & 0.01 \\
\hline
\end{tabular}

* Statistically significant $(p<0.01)$

Table 5 shows that gender impacted significantly on the combined dependent variable Ill health $\left(F_{(2,592)}=12.82, p<0.01\right.$; Wilks' Lambda $=0.96$; partial $\left.\eta^{2}=0.04\right)$. However, this effect was moderate ( $4 \%$ of the variance explained). Analysis of each dependent variable, using a Bonferroni adjusted alpha level of 0.025 , showed that academics differed in terms of the level of Physical Ill health $\left(F_{(2,}\right.$ ${ }_{594)}=24.6, p<0.01$, partial $\left.\eta^{2}=0.04\right)$. Female academics experienced more physical ill health problems than male academics.

Table 5 shows that age impacted significantly on the combined dependent variable Ill health $\left(\mathrm{F}_{(8}\right.$, $1170)=3.39, p<0.01$; Wilks' Lambda $=0.96$; partial $\left.\eta^{2}=0.02\right)$. However, this effect was moderate ( $2 \%$ of the variance explained). Analysis of each dependent variable, using a Bonferroni adjusted alpha level of 0.025 , showed that academics differed in terms of the level of Physical Ill Health $\left(F_{(4,}\right.$ ${ }_{590)}=5.24, p<0.01$, partial $\left.\eta^{2}=0.04\right)$ and Psychological Ill Health $\left(\mathrm{F}_{(4,590)}=5.13, p<0.01\right.$, partial $\left.\eta^{2}=0.03\right)$. Academics aged 30 to 39 years experienced more physical ill health problems than academics aged 60 to 69 years. Academics between the ages of 40 and 49 years experienced more psychological ill health problems than academics aged between 60 and 69 years.

Results furthermore showed no significant differences in terms of ill health for academics with different academic ranks.

Next, multiple regression analyses were conducted with occupational stressors as independent variables, and Physical Ill Health, Psychological Ill Health, Individual Commitment to the Organisation and Organisational Commitment to the Individual, respectively, as dependent variables.

Table 6 shows that occupational stressors explained 13 percent and 28 percent of the variance in Physical and Psychological Ill Health respectively. Two occupational stressors, namely Overload and Work-life Balance were statistically significant predictors of Physical Ill Health. Occupational stressors explained 33 percent of the variance in Individual Commitment to the Organisation. The regression coefficients of four occupational stressors were statistically significant, namely Overload $(\beta=0.24)$, Job Control $(\beta=-0.18)$, Resources and Communication $(\beta=-0.17)$, and Job Characteristics $(\beta=0.22)$. Occupational stressors explained 19 percent of the variance in the perceived Commitment of the Organisation to the Individual. Again, the regression coefficients of four occupational stressors were statistically significant, namely, Overload $(\beta=0.18)$, Job Control $(\beta=-0.18)$, Resources and Communication $(\beta=-0.21)$, and Job Characteristics $(\beta=0.22)$.

\section{DISCUSSION}

The objectives in this study were to identify indicators of occupational stress for academic staff in South African higher education institutions, to analyse differences between the occupational stress levels of different demographic groups, and to investigate which occupational stressors best predict ill health and organisational commitment. Compared to the normative data, academics experienced high levels of occupational stress relating to pay and benefits, overload and work-life balance. Despite reporting above-average levels of psychological ill health, academics also experienced average levels of commitment both from and towards the organisation. Analysis of variance revealed differences between the levels of occupational stress and ill health of the demographic groups. 
Table 6. Standard multiple regression analyses

\begin{tabular}{|c|c|c|c|c|c|c|c|}
\hline \multirow{2}{*}{ Variable } & \multicolumn{2}{|c|}{$\begin{array}{c}\text { Unstandardised } \\
\text { Coefficient }\end{array}$} & \multirow{2}{*}{$\begin{array}{c}\begin{array}{c}\text { Standardised } \\
\text { Coefficient }\end{array} \\
\text { Beta }\end{array}$} & \multirow{2}{*}{$t$} & \multirow{2}{*}{$p$} & \multirow{2}{*}{$\boldsymbol{F}$} & \multirow{2}{*}{$\boldsymbol{R}^{2}$} \\
\hline & B & SE & & & & & \\
\hline Physical IIl health & & & & & & $10.65^{*}$ & 0.13 \\
\hline (Constant) & 7.45 & 0.74 & & 10.10 & 0.00 & & \\
\hline Work Relationships & 0.02 & 0.04 & 0.03 & 0.45 & 0.65 & & \\
\hline Work/life Balance & 0.12 & 0.05 & 0.13 & 2.63 & $0.01 *$ & & \\
\hline Job Overload & 0.14 & 0.06 & 0.14 & 2.50 & $0.01 *$ & & \\
\hline Job Security & 0.10 & 0.05 & 0.09 & 2.06 & 0.04 & & \\
\hline Job Control & 0.03 & 0.06 & 0.03 & 0.54 & 0.59 & & \\
\hline Resources and & -0.01 & 0.06 & -0.01 & -0.11 & 0.92 & & \\
\hline \multicolumn{8}{|l|}{ Communication } \\
\hline Job Characteristics & 0.06 & 0.04 & 0.08 & 1.45 & 0.15 & & \\
\hline Pay and Benefits & 0.04 & 0.11 & 0.01 & 0.33 & 0.74 & & \\
\hline Psychological III Health & & & & & & $28.59 *$ & 0.28 \\
\hline (Constant) & 8.97 & 1.08 & & 8.31 & 0.00 & & \\
\hline Work Relationships & 0.04 & 0.05 & 0.04 & 0.74 & 0.46 & & \\
\hline Work/life Balance & 0.21 & 0.07 & 0.14 & 3.12 & $0.00 *$ & & \\
\hline Job Overload & 0.38 & 0.08 & 0.24 & 4.73 & $0.00 *$ & & \\
\hline Job Security & 0.12 & 0.07 & 0.07 & 1.77 & 0.08 & & \\
\hline Job Control & 0.13 & 0.09 & 0.09 & 1.48 & 0.14 & & \\
\hline Resources and & 0.14 & 0.09 & 0.08 & 1.53 & 0.13 & & \\
\hline \multicolumn{8}{|l|}{ Communication } \\
\hline Job Characteristics & 0.10 & 0.06 & 0.08 & 1.60 & 0.11 & & \\
\hline Pay and Benefits & -0.13 & 0.17 & -0.03 & -0.79 & 0.43 & & \\
\hline $\begin{array}{l}\text { Commitment (Individual } \\
\text { - Organisation) }\end{array}$ & & & & & & $35.31 *$ & 0.57 \\
\hline (Constant) & 31.29 & 0.78 & & 40.10 & 0.00 & & \\
\hline Work Relationships & -0.06 & 0.04 & -0.08 & -1.53 & 0.13 & & \\
\hline Work/life Balance & -0.04 & 0.05 & -0.04 & -0.89 & 0.37 & & \\
\hline Job Overload & 0.21 & 0.06 & 0.18 & 3.57 & $0.00 *$ & & \\
\hline Job Security & -0.10 & 0.05 & -0.07 & -1.97 & 0.05 & & \\
\hline Job Control & -0.25 & 0.07 & -0.22 & -3.91 & $0.00 *$ & & \\
\hline Resources and & -0.22 & 0.06 & -0.17 & -3.47 & $0.00 *$ & & \\
\hline \multicolumn{8}{|l|}{ Communication } \\
\hline Job Characteristics & -0.22 & 0.05 & -0.22 & -4.76 & $0.00 *$ & & \\
\hline Pay and Benefits & -0.27 & 0.12 & -0.09 & -2.26 & 0.02 & & \\
\hline $\begin{array}{l}\text { Commitment (Organisa- } \\
\text { tion - individual) }\end{array}$ & & & & & & $17.47^{*}$ & 0.19 \\
\hline (Constant) & 23.41 & 0.65 & & 36.04 & 0.00 & & \\
\hline Work Relationships & 0.01 & 0.03 & 0.01 & 0.24 & 0.81 & & \\
\hline Work/life Balance & 0.00 & 0.04 & 0.00 & 0.02 & 0.98 & & \\
\hline Job Overload & 0.16 & 0.05 & 0.18 & 3.35 & $0.00 *$ & & \\
\hline Job Security & 0.01 & 0.04 & 0.01 & 0.23 & 0.82 & & \\
\hline Job Control & -0.16 & 0.05 & -0.18 & -2.88 & $0.00 *$ & & \\
\hline Resources and & -0.20 & 0.05 & -0.21 & -3.71 & $0.00 *$ & & \\
\hline \multicolumn{8}{|l|}{ Communication } \\
\hline Job Characteristics & -0.16 & 0.04 & -0.22 & -4.34 & $0.00 *$ & & \\
\hline Pay and Benefits & -0.20 & 0.10 & -0.08 & -2.04 & 0.04 & & \\
\hline
\end{tabular}

* Statistically significant $(p<0.01)$ 
Results in this study showed that, compared to the normative data, academics experienced high levels of occupational stress relating to pay and benefits, overload and work-life balance. These sources of stress further encompass the main causes of stress in universities identified in previous research (i.e. Abouserie, 1996; Association of University Teachers, 2003; Gillespie et al. 2001; Kinman, 1998; Winefield et al., 2002).

With regard to overload, academics felt particularly stressed by the time constraints placed upon them. Consequently, and in line with Kinman and Jones (2003), academics perceive that they do not perform their jobs (i.e. research and teaching) as well as they would like to. Results further showed that academics are set unrealistic deadlines to perform unmanageable workloads, which according to Gillespie et al. (2001), are likely to increase their stress levels. Moreover, findings also highlighted the significant impact that occupational stress was having on the academics' family life. Consistent with the findings of Kinman and Jones (2003), academics in this study indicated that they worked longer hours than they chose to or want to and often during weekends. Ultimately, these two factors contributed to the high levels of occupational stress academics experienced regarding work-life balance.

In comparison to the normative data, academics were less troubled by work relationships, job security, control, resources and communication and job characteristics. In line with previous studies, it seems that academics still have a considerable degree of control over their jobs (Kinman, 1998) and do not have problems dealing with, for instance, difficult students as part of their overall job (Tytherleigh et al., 2005). Given the fact that job characteristics are a predictor of job satisfaction, one can argue in support of previous findings, that academics are relatively satisfied with their jobs in spite of the perceived stressors and strains (Doyle \& Hind, 1998; Watts et al. 1991). However, in contrast to other studies (Gillespie et al., 2001; Tytherleigh et al. 2005), academics did not experience high levels of stress relating to job security. This is quite remarkable since tertiary education institutions in South Africa are continually being faced with major changes such as reframing, restructuring, revitalisation and renewal (Viljoen \& Rothmann, 2002).

Results showed that academics with a five- to seven-year degree and associate professors in general, experienced the highest level of job demands. In this regard, Osipow et al. (1985) suggested that as people age and gain in experience and status within the organisation, they appear to take on additional responsibilities and consequently experience an increase in job demands. Dua (1994) for example found that staff above senior level are more stressed because of higher workloads. Furthermore, Winter et al. (2000) found that associate professors are more likely to experience role overload than academics employed at lower ranks. Role overload again has been found to be a salient stressor in academic work-life (Fisher, 1994; Lease, 1999). Regarding qualification, these results do not support the findings of Dua (1994) that academics with higher levels of qualifications are more likely to experience stress than those with lower qualifications. Consistent with previous studies (i.e. Abouserie, 1996; Gmelch \& Burns, 1994; Dua, 1994) no significant differences regarding occupational stress were found between male and female academics.

The wealth of literature is also quite clear about the devastating impact of stress on the academic. In this study, academics experienced extremely high levels of psychological ill health (sten score of ten). In line with Gillespie et al. (2001), factors such as constant irritability, avoiding contact with other people, feeling unable to cope and feeling or becoming angry with others too easily were some of the main factors contributing to academics' low levels of psychological well-being. Although academics had average scores on physical ill health, they were troubled with sleep loss and muscular tension/ aches and pains (see Winefield et al. 2002).

Female academics reported higher levels of physical ill health than male academics. According to Blix et al. (1994), women working in higher education experience more stressors and strains than their male counterparts as a result of a lack of role models and increased role conflict as they 
endeavour to balance roles at work and at home. Hayes (1986) for instance noted that the demands on women's time coupled with role conflicts and the absence of mentors negatively affect their health, work and relationships. Based on the findings of Osipow et al. (1985), results in this study showed that older academics (60 to 69 years) were less troubled by physical and psychological ill health problems. This may be because as people get older they become more experienced and more worldly-wise and consequently adopt more rational cognitive coping mechanisms than younger academics (Dua, 1994; Osipow et al. 1985). No significant differences were found regarding ill health problems for academics with different academic ranks.

Regardless of the stressors and strains reported in this study, academics still experienced average levels of commitment both from and towards the organisation. These results partially support the findings of another South African study (Coetzee \& Rothmann, 2005), indicating that university staff are likely to be committed to their organisation, but contradict the findings of Tytherleigh et al. (2005) suggesting that all university staff perceived low commitment both from and to the organisation.

The multiple regression analyses showed that stress about overload and work-life balance contributed significantly to physical ill health. A study by Allen, Herst, Bruck, and Sutton (2000), also showed that stress about work-life balance result in burnout and physical consequences such as headache, backache, upset stomach, fatigue and sleep deprivation. Furthermore, stress about workload also result in physical ill health symptoms. These two stressors (overload and work-life balance) explained twice as much of the variance in psychological unwell-being (compared to physical ill health). It is clear from these results that stress because of overload and work-life balance are important contributing factors to ill health of academics in higher education institutions. Ill health could result in sickness, absenteeism and early retirements in higher education institutions.

Multiple regression analyses also confirmed that four occupational stressors, namely, high stress because of overload, and low stress because of job control, resources and communication, and job characteristics contributed significantly to the affective commitment of academics to their institutions. These stressors also impacted significantly on perceptions of academics that the institution is committed to them. It seems that organisational commitment of academics in higher education institutions will be reduced when they experience stress because of a lack of autonomy in their jobs, if they lack the appropriate training, equipment and resources, and if they find the inherent characteristics of their jobs as stressful. These stressors could result in staff turnover.

The present study also had some limitations. One of these derives from the fact that the present set of results was based on a cross-sectional data set. Therefore, it is inappropriate to speak of job stressors 'affecting' the outcome variables. All that has been shown is that the pattern of the effects is consistent with theoretical notions regarding the temporal order of the variables. Only longitudinal research can solve the issue of the causal order of these variables. Lastly, the results were based on self-report measures, which are likely to increase at least part of the shared variances between measures.

\section{RECOMMENDATIONS}

With the accumulated evidence that occupational stress leads to adverse health outcomes, occupational stress research has reached the stage of intervention (Kompier \& Kristensen, 2001). These authors further distinguish between primary-, secondary- and tertiary-level interventions. Primarylevel interventions are concerned with modifying or eliminating the stressor inherent to the workplace in order to adapt the environment to better fit the individual. In the academic context, more equitable reward systems may reduce the high levels of stress academics experience regarding pay and benefits. Since overload also plays a central role in the process that may lead to stress and health problems, reducing overload seems warranted. In line with Abouserie (1996), it is suggested that more research 
assistants and tutors be recruited to help in doing research and teaching and thus ease the time constraints and other pressures on academia. It is furthermore believed that a reduction in job demands will also help academics to achieve a more healthy balance between their work and home domains.

Secondary-level interventions can be implemented for academics who are already showing signs of stress from getting sick and in order to increase their coping capacity. It may be useful to organise stress management courses for academic staff to introduce them to more appropriate ways of managing stress. Cognitive structuring, time management and conflict resolution would be applicable in this context. Tertiary-level interventions are concerned with the rehabilitation of individuals who have suffered ill health or reduced well-being as a result of stress in the workplace. Given the extremely high score of psychological ill health and also suicide ideation among academics, such interventions are warranted.

Furthermore, stress-reduction approaches in the workplace could be improved by implementing a theoretical model. The ASSET model in particular has been used in a wide variety of occupations including health care, transportation, and now academia. However, further refining and testing of the ASSET is needed, especially within the South African context. Cooper, Dewe, and O'Driscoll (2001) suggested that in order to minimise the negative spin-offs of occupational stress, it is important to take a holistic approach to the stress and strain of the employee. Finally, it is recommended that future studies of occupational stress should adhere to the multi-cultural context of the South African workforce.

\section{ACKNOWLEDGEMENT}

This research is based on work supported by the National Research Foundation under Grant number 2053344.

\section{REFERENCES}

Abouserie, R. (1996). Stress, coping and job satisfaction in university academic staff. Educational Psychology, 16, 49-56.

Allen, T. D., Herst, D. E., Bruck, C.S., \& Sutton, M. (2000). Consequences associated with work-to-family conflict: a review and agenda for future research. Journal of Occupational Health Psychology, 5 , 278-308.

Association of University Teachers. (2003). Survey of members. London: AUT.

Begley, T. M., \& Cazjka, J. M. (1993). Panel analysis of the moderating effects of commitment on job satisfaction, intent to quit, and health following organisational change. Journal of Applied Psychology, $78,552-556$.

Blix, A. G., Cruise, R. J., Mitchell, B. M., \& Blix, G. G. (1994). Occupational stress among university teachers. Educational Research, 36, 157-169.

Boyd, S., \& Wylie, C. (1994). Workload and stress in New Zealand Universities. Wellington: New Zealand Council for Educational Research and the Association of University Staff of New Zealand.

Cartwright, S., \& Cooper, C.L. (2002). ASSET: An Organisational Stress Screening Tool - The Management Guide. Manchester, UK: RCL Ltd.

Chow, I. H. S. (1990). An empirical assessment of organisational commitment among local employees. Human Resources Journal, 6, 32-38.

Chui, R. K., \& Kosinski, F. A. Jr. (1995). Chinese cultural collectivism and work-related stress: implications of employment counselors. Journal of Employment Counseling, 32, 98-110.

Clarke, S. G., \& Cooper, C. L. (2000). The risk management of occupational stress. Health, Risk \& Society, 2, 173-187.

Coetzee, S. E., \& Rothmann, S. (2005). Occupational stress in a higher education institution in South Africa. South African Journal of Industrial Psychology, 31, 47-54.

Cooper, C. L. (1999). The changing psychological contract at work. European Business Journal, 11, $115-118$.

Cooper, C. L., Dewe, P. J., \& O'Driscoll, M.P. (2001). Organisational stress: A review and critique of 
theory, research, and applications. San Francisco, CA: Sage Publications.

Cooper, C. L., \& Cartwright, S. (1994). Health mind, healthy organisation: A proactive approach to occupational stress. Human Relations, 4, 455-471.

Cooper, C. L., \& Marshall, J. (1976). Occupational sources of stress: A review of the literature relating to coronary heart disease and mental ill health. Journal of Occupational Psychology, 49, 11-28.

Cross, G., \& Carroll, D. (1990). Goodwill under stress: Morale in UK universities. London: Association of University Teachers.

Daniels, K., \& Guppy, A. (1994). An exploratory study of stress in a British University. Higher Education Quarterly, 48, 135-144.

Doyle C., \& Hind, P. (1998). Occupational stress, burnout and job status in female academics. Gender, Work and Organisations, 5, 67-82.

Dua, J. K. (1994). Job stressors and their effects on physical health, emotional health and job satisfaction in a university. Journal of Educational Administration, 32, 59-78.

Fisher, S. (1994). Stress in academic life: The mental assembly line. Buckingham, UK: Open University Press.

French, J., Caplan, R., \& van Harrison, R. (1982). The mechanisms of job stress and strain. New York: Wiley.

Gillespie, N. A., Walsh, M., Winefield, A. H., Dua, J., \& Stough, C. (2001). Occupational stress in universities: Staff perceptions of the causes, consequences and moderators of stress. Work \& Stress, $15,53-72$.

Gmelch, H. G., Wilke, P. K., \& Lovrich, N. P. (1986). Dimensions of stress among university faculty: Factor-analytic results from a national study. Research in Higher Education, 24, 266-286.

Gmelch, W. G., \& Burns, J. S. (1994). Sources of stress for academic department chairpersons. Journal of Educational Administration, 32, 79-94.

Goldberg, D. P., \& Williams, P. (1988). A user's guide to the GHQ. London: NFER, Nelson.

Hayes, L. S. (1986). The superwoman myth. Social Casework, 7, 436-441.

Hind, P., \& Doyle, C. (1996). A cross-cultural comparison of perceived occupational stress in academics in higher education. Paper presented at the XXVI International Congress of Psychology, Montreal, Canada.

Johnson, S., \& Cooper, C. (2003). The construct validity of the ASSET stress measure. Manuscript made available by authors.

Kahn, R. L., Wolfe, D. M., Quinn, R. P., Snoek, J. D., \& Rosenthal, R. A. (1964). Role stress: Studies in role conflict and ambiguity. New York: John Wiley.

Karasek, R., \& Theorell, T. (1990). Healthy work, stress, productivity and the reconstruction of working life. New York: Basic Books.

Kelly, S., Charlton, J., \& Jenkins, R. (1995). Suicide deaths in England and Wales, 1982-1992: The contribution of occupation and geography. Population Trends, 80, 18-21.

Kinman, G. (1996). Occupational stress and health among lecturers working in further and higher education. London: National Association of Teachers in Further and Higher Education.

Kinman, G. (1998). Pressure points: A survey into the causes and consequences of occupational stress in the UK academic and related staff. London: Association of University Teachers.

Kinman, G. (2001). Pressure points: A review of research on stressors and strains in UK academics. Educational Psychology, 21, 473-492.

Kinman, G., \& Jones, F. (2003). Running up and down the escalator: Stressors and strains in UK academics. Quality in Higher Education, 9, 21-38.

Kompier, A. J., \& Kristensen, T. S. (2001). Organisational work stress interventions in a theoretical, methodological and practical context. In J. Dunham (ed.), Stress in the workplace: Past, present and future (pp. 19-33). London: Whurr Publishers.

Lazarus, R. S. (1991). Psychological stress in the workplace. In P.L. Perrewé (ed.), Handbook on job stress (pp. 1-13). Corte Madera, CA: Select Press.

Lease, S. H. (1999). Occupational role stressors, coping, support and hardiness as predictors of strain in academic faculty: An emphasis on new and female faculty. Research in Higher Education, 40, 285-307.

McInnis, C. (1999). Change and diversity in work patterns of Australian academics. Higher Education 
Management, 8, 105-117.

Meyer, J. P., \& Allen, N. J. (1997). Commitment in the workplace: Theory, research and application. Thousand Oaks, CA: Sage.

Millward-Brown. (1996). Powerful people: A survey of Britain's professional workforce. London: Guardian Publishing.

Nunnally, J. C., \& Bernstein, I. H. (1994). Psychometric theory (3rd edn). New York: McGraw-Hill.

Osipow, S. H., Doty, R. E., \& Spokane, A. R. (1985). Occupational stress, strain and coping across the life span. Journal of Vocational Behavior, 27, 98-108.

Richard, G. V., \& Krieshok, T. S. (1989). Occupational stress, strain and coping in university faculty. Journal of Vocational Behavior, 34, 117-132.

SAS Institute. (2000). The SAS System for Windows: Release 8.01. Cary, NC: SAS Institute Inc.

Selye, H. (1976). The stress of life. New York: McGraw-Hill.

Sharpley, C. F., Reynolds, R., Acosta, A., \& Dua, J. K. (1996). The presence, nature and effects of job stress on physical and psychological health at a large Australian university. Journal of Educational Administration, 34, 73-86.

Sommer, S. M., Bae, S., \& Luthans, F. (1996). Organizational commitment across cultures: The impact and antecedents on Korean employees. Human Relations, 49, 977-993.

Sorcinelli, M. D. (1994). Effective approaches to new faculty development. Journal of Counselling and Development, 72, 474-479.

Sparks, K., \& Cooper, C. L. (1997). The effects of hours of work on health: A meta-analysis review. Journal of Occupation and Organizational Psychology, 70, 391-408.

SPSS Inc. (2003). SPSS 12.0 for Windows. Chicago, IL: Author.

Tabachnick B.G., \& Fidell, L.S. (2001). Using multivariate statistics (4th edn.). Boston, MA: Allyn \& Bacon.

Taris, T. W., Schreurs, P. J. G., \& van Iersel-van Silfhout, I. J. (2001). Job stress, job strain, and psychological withdrawal among Dutch university staff: Towards a dual-process model for the effects of occupational stress. Work \& Stress, 15, 283-296.

Tytherleigh, M. Y. (2003). What employers may learn from higher education institutions: A fortigenic approach to occupational stress. SA Journal of Industrial Psychology, 4, 101-106.

Tytherleigh, M. Y., Webb, C., Cooper, C. L., \& Ricketts, C. (2005). Occupational stress in UK higher education institutions: A comparative study of all staff categories. Higher Education Research \& Development, 1, 41-61.

Viljoen, J. P., \& Rothmann, S. (2002). Transformation in a tertiary-education institution: A case study. Management Dynamics, 11, 2-10.

Watts, W. D., Cox, L., Wright, L. S., Garrison, J., Herkimer, A., \& Howze, H. H. (1991). Correlates of drinking and drug use by higher education faculty and staff: Implications for prevention. Journal of Drug Education, 21, 43-64.

Winefield, A. H., Gillespie, N., Stough, C., Dua, J., \& Hapuararchchi, J. (2002). Occupational stress in Australian Universities: A national survey. Melbourne: National Tertiary Education Union.

Winter, R., Taylor, T., \& Sarros, J. (2000). Trouble at mill: Quality of academic work life issues within a comprehensive Australian university. Studies in Higher Education, 25, 279-294. 